\title{
Multi-Sensory Approach: How It Helps in Improving Words Recognition?
}

\author{
Nurul Akmal Amirah Sarudin'1,2, Harwati Hashim²*, Melor Md. Yunus² \\ ${ }^{1}$ SJKC Sang Lee, Raub, Malaysia \\ ${ }^{2}$ Faculty of Education, Universiti Kebangsaan Malaysia, Selangor, Malaysia \\ Email: ^harwati@ukm.edu.my
}

How to cite this paper: Sarudin, N. A. A. Hashim, H., \& Yunus, M. Md. (2019). MultiSensory Approach: How It Helps in Improving Words Recognition? Creative Education, 10, 3186-3194. https://doi.org/10.4236/ce.2019.1012242

Received: October 16, 2019

Accepted: November 27, 2019

Published: November 30, 2019

Copyright (c) 2019 by author(s) and Scientific Research Publishing Inc. This work is licensed under the Creative Commons Attribution International License (CC BY 4.0).

http://creativecommons.org/licenses/by/4.0/

(c) (i) Open Access

\begin{abstract}
The Malaysian Education Blueprint is aimed to make sure that every child can master all the skills including listening, speaking, reading and writing. Hence, the English Language syllabus is designed to mould the pupils to become a skilful learner at an early age. One of the skills that they have acquired as early as in Standard 1 is the reading skills. There are varieties of strategies that can be used by the teachers to help the learners' performance in mastering reading skills. One of them is through the multi-sensory approach where it involves the learners' senses throughout the activities done in the classroom. Therefore, this paper discusses how multi-sensory approach can be used as a strategy to improve learners' reading skills by improving their word recognition. It aims to explore past studies on the effective use of visual, auditory and tactile aids in the classroom as well as the learners' kinaesthetic experiences in improving their word recognition.
\end{abstract}

\section{Keywords}

Multi-Sensory Approach, Word Recognition, Reading Skills, Effective Use

\section{Introduction}

It is a priority to the government in getting Malaysians to master the English language as the language played an important role in nation-building (Shah, Othman, \& Senom, 2017; Thirusanku \& Yunus, 2014; Hashim \& Isa, 2012). In line with this, initial steps need to be taken especially for primary education where English teachers need to enhance the learners' English skills (Abdullah, Yunus, \& Hashim, 2019; Zulkiflei, Yunus, \& Hashim, 2017). One of the four skills in the English language that learners have to master is reading skills. Word recognition is an extremely important skill that the children need before they 
will be ready to grasp the concept of reading. This is in line with one of the Year 2 learning standard where learners should be able to read and apply word recognition and word attack skills by matching words with spoken words. Without the ability to recognize words, the reading process cannot proceed. The more words children recognize, the easier it is for them to read. This proves how important word recognition is in reading.

However, it has been discovered that most of the grade 2 learners, especially in the remote area were not able to complete the task given by the teacher due to their lack of literacy skills in word recognition (Yunus, Salehi, \& John, 2013). If this problem is not solved at this early stage, it will probably triumph over to secondary school (Don-Ezenne, 2014). Past literature has documented that, learners were able to state the name of certain things but when they are shown the written words; they were not able to read it correctly. If a printed word is not in a reader's meaning vocabulary, word-identification skills may allow access to the word's pronunciation, but not it's meaning (Chard, 2000). This shows that learners were unable to match the spoken words with the written words which prove that they have problems in word recognition. Hence, teachers need to tackle this issue by deciding which strategies are the most suitable to be used to overcome this issue. There are a lot of strategies and techniques that have been used to help those learners including multisensory approach. This approach is hoped to help those learners who are struggling in reading by engaging in the activities that involve their visual, auditory, kinaesthetic and tactile.

\section{Multi-Sensory Approach}

The Department for Education and Skills (DfES) (2004) defines multi-sensory as: "using visual, auditory and kinaesthetic modalities, sometimes at the same time" (Obaid, 2013). This implies that multi-sensory approach is the use of strategies involving human senses including visual (what we see), auditory (what we hear), kinaesthetic and tactile (what we do or feel) to enhance learning. All these strategies can help to retain information in learners' brain for the long term in its real sense through seeing, hearing, touching and feeling. This approach encourages learners to learn from their experiences by using more than one sense.

According to Maheshwari (2016), the process of using these strategies occurred naturally and it starts even before birth. The infants usually learn about their surrounding through observing, listening including putting everything within reach into their mouths. When they grew up as toddlers, they tend to touch or grab everything they see around them, when they reached the preschoolers' age, they will ask about their surroundings even sometimes it seems like millions of questions. Based on this, we rarely have to teach them how to do these things since they are learning in a very natural way. This will enable the teachers to use the same energy and strategy to proceed with the process in their classrooms. 
When teachers use this approach to teach the learners, they will indirectly encourage the learners to gather information about a task. When they have gone through the learning experience by doing various kind of activities, this will help them to gather the information and store it in their brain better compared to using only hearing and seeing senses as it gives more ways to remember the input and more ways to recall it in their learning later. Not only that, but it also aids learners to link the information to ideas they already know and understand from conducting different types of activities. This is because the learners are taught by including all the senses into the learning process which activate different parts of the brain simultaneously and indirectly enhance the memory and the learning of written language.

Apart from the effectiveness of the strategies itself, using the multi-sensory approach in the learning process can provide a fun learning experience to the learners. This is due to various materials used during the learning process to inculcate all the senses through the activities. From this, learners will not be getting bored since they are moving around and use the function of their senses instead of only learning through chalk and talk. Due to this, it will help to increase their understanding and strengthening their skills since not only they use the five senses but they can learn in a non-threatening environment as well.

\section{Multi-Sensory Approach in Learning}

Literacy skills have been a major part in English language teaching especially when it involves reading activities. In relation, there are several stages of reading involving word recognition, comprehension, fluency, and motivation (DonEzenne, 2014). Word recognition is the fundamental basis in the earliest stage of reading which students need to master before proceeding to the next stages. According to Don-Ezenne (2014) in his study, word recognition requires learners to identify the words in print to construct understanding and making meaning so that reading is automatic and accurate. Therefore, teachers need to overcome any problems related to the word recognition as it is the most important element when teaching reading as well as literacy skills.

Teachers believe that not all learners can master the word recognition at the same pace. Some learners found it difficult to identify even a letter especially for those who are mild intellectually disabled as teaching them is more complicated than teaching it to the normal one (Mohammadein, 2016). In accordance, there are many researchers conducted to find out what is the most suitable technique to help the learners in improving word recognition which one of it is a multisensory approach. Moustafa \& Ghani (2016) in his study stated that this approach is to teach learners to read through the use of different senses while Davis (2011) believes that learners can learn better by remembering the letters if they are allowed to see, pronounce and write the letters.

Throughout this approach, learners are given treatment using various kind of activities involving their senses such as auditory, kinaesthetic, visual and tactile. Philips \& Feng (2012) stated that when learners are able to move in some ways 
and interact and converse with others in addition to seeing a demonstration or model of a task or concept, they are more likely to achieve (Platt, 2015). By using this approach, it is believed that it can help to improve learners' word recognition as they will be enjoying such activities where the teacher provides them with a fun learning environment. This is proven in a study conducted by Philips \& Feng (2012) where they stated that participants were engaged and liked the process. When learners are able to construct meaning, they next can proceed to spelling stage by using this approach as it is believed that using multisensory activities had a positive impact on learners for practicing learning their spelling words (Jasmine \& Conolly, 2015). Therefore, it was proven by previous researches that multi-sensory approach is able to help the learners in terms of increasing their reading skills.

\section{Effective Use of Visual Aids in the Classroom}

There are a lot of examples of activities that can be conducted using visual for improving learners' word recognition. One of the examples is teachers can use flashcard with pictures by reading and looking at the pictures repeatedly. Teachers need to encourage the learners to say the words aloud and pointing out at the pictures at the same time in repetition so that it will help to strengthen their memory for later learning process since the brain can register 36,000 visual images per hour (Wilmes et al., 2008).

Secondly, another example of visual activities that can be done with the slow learners is the use of printable books where learners can read the short books emphasizing on the sight words, word families as well as short or long vowels. From this activity, teachers can ask the learners to underline the focus words with colourful markers based on the preference such as all the short "a" words, etc. Third example activity is to have the learners watch what they look like when saying letters in the mirror. Make sure to have them see the shape of their mouths while pronouncing each word for example when they make the sound of the letter "O". Also, teachers can ask them to see the position of their tongues especially when they make the sound "sh" and "th". This will make them keep practicing the correct pronunciation of the words by having that visual in the mirror which then will be stored in their brain. Hence, they will quickly remember how to read when they come across the same pronunciation which helps them to improve their word recognition.

Hence, visual activities implemented in the classroom is able to do more than simply enrich learning. Visual stimulation is essential to learning because it is necessary for understanding. Imagery is what helps the learners to comprehend and remember the material. While it may be possible to recite abstract concepts, they are not truly understood until imagery is evoked (Ewy, 2003).

\section{Effective Use of Auditory Aids in the Classroom}

The most used activity when it comes to auditory is the use of songs. According 
to Johnson \& Edelson (2003), Music is believed to enhance spatial-temporal reasoning, which is necessary for concepts such as proportional reasoning and geometry. This implies that the use of songs is effective to be inculcated in the learning process which is improving the words recognition. Teachers might want to introduce the songs to the learners first before they learn the words. Through the songs, learners can pronounce it several times and have it listened by themselves until they can pronounce it correctly before starting the lesson specifically and explaining the meaning of the words.

Secondly, teachers can conduct the reading aloud activities. Learners can do this activity with the teachers or pair up with their friends. When they do this with the teachers, they can immediately be corrected if there are any mistakes made while pronouncing the words. Teachers also need to teach the learners on how to listen to the words pronounce by themselves attentively. After they can pronounce it perfectly, they can do the practice with their friends and listen to each other. When they are able to correct their friends, it will increase their confidence and motivate them to learn more in a fun way. Next activity that can be applied with the learners in the classroom is phonemic awareness. This is verbal and auditory activity which prepare the learners for reading print. They will get to learn on how to segment and blend the sounds and listen to themselves. This can be conducted by playing around in many ways such as throwing balls for each letter sound, jump or clap. This kind of activities are more likely to be likeable by the learners as they get to move around instead of sitting still on their chairs listening to the teachers.

Therefore, auditory activities are believed to engage the whole brain as it can assist the learners in memorizing the words through listening. This ensures that the students are engaging their brains to their fullest capabilities, which increases the likelihood of remembering the material (Jensen, 1998; Wilmes et al., 2008).

\section{Effective Use of Tactile Aids in the Classroom}

Tactile learning includes feeling and touch. Teachers use anything textured or raised to help with tactile learning such as coins, sand, dice, and clay. This learning techniques often engages fine motor skills so it may challenge children who struggle with this (Maheshwari, 2016).

There are a few tactile activities that can be conducted with the learners. One of them is to use playdough. Learners can create words or letters by shaping the playdough according to the shape of the letters. Teachers can give papers with outlined words and learners will follow the shape of the letters on the paper with the playdough. When doing this, learners not only can see the letters that they have shaped by themselves but also know how to write it later.

Another suggested activity that can be implemented is through the Montessori technique which is sandpaper letters. In this activity, learners will trace letters made of sandpaper by using their fingers. When doing this, they will be able to retain a tactile memory of the feel of the letters. Apart from using sandpaper let- 
ters, learners can also write the words on air, using salt or shaving cream, and many more depends on the creativity of the teachers. From this, learners will learn best by enjoying what they did with their friends. Third example activity that can be done is to do hidden sight word painting. Before asking the learners to write the words on the paper, teachers can ask them to paint over the words using watercolour. As they paint the sight words will appear and they can have a contest to see who could paint over all the sight words and read them all first correctly. By enjoying this activity, the learners will try their best to paint the words and read them correctly to win the contest.

Thus, as suggested by Wesson (2002) in Maheshwari (2016), learners learn best when they use their senses to study new objects in order to understand them better.

\section{Effective Use of Kinaesthetic Experiences in the Classroom}

Researchers discovered that the part of the brain that processes movement is the same part that processes learning. Thus, movement is believed to stimulate learning (Stoffers, 2011). Various of kinaesthetic activities have been done in previous studies to improve the learners' word recognition. One of them is sight word jump where teachers paste the words high on the wall. Then, the learners need to jump for the words when it is called out by the teacher. This activity needs to be done one by one for the learners because if they are to do it along with their friends, they might tend to follow their friends' answers and got it right without even thinking. When they do it alone by themselves make sure that it is okay for them to take time to think of which words were called out by the teacher which is to make sure that the learning process occurs.

Another kinaesthetic activity that is interesting for the learners is sight word towers. In this activity, teachers need to write the words on the paper cups and have the learners to read it. If the learners can read the words correctly, they can add another cup to their tower until it is high. They will need to take down one cup if they pronounce the words incorrectly. This will make the learners compete on who will be getting the highest tower cup in a short amount of time which might be the learners' favourite activity. Apart from that, learners can also have a race car blending. This is a phonemic awareness activity where the learners use a toy car to drive across the letters written spaced across a racetrack to make a word. As they drive across it, they will have to sound out the letters. If they were to drive slowly, they will have to sound out the letters slowly and segment them into words. If they drive the toy car faster, they will need to say the words clearly, loudly and quickly. Such fun activity can provide a fun learning environment to the learners which help to motivate them in their learning process.

Based on all the activities suggested, it can be seen that the learners can move around which created a fun learning environment for them. By doing this, it aids the learners to remember better as Students who learn kinaesthetically will be 
able to remember the movements of the body and use this as a bridge to make connections to the information learned (Skoning, 2010).

\section{Conclusion}

The multisensory approach enables to help learners with learning difficulties in one or more areas including reading, spelling, writing, math, listening comprehension and expressive language. This can help the learners to use their personal areas of strength as their preferred strategies to help them learn. They will be able to range from simple to complex, depending on the needs of the learners and the task at hand. When the learners know what suits them the most in their learning, it will help to motivate them to keep practicing to improve their word recognition. This will slowly aid to boost their confidence level as well as improving their reading skills.

As for the teachers, according to an article in UK Essays, "research shows that by using varying teaching strategies teachers can address all sensory preference and increases learning regardless of the individual student's primary preference (Thomas, Cox \& Kojima, 2000)". This postulated that by using the multi-sensory approach to improve learners' word recognition teachers can use various kind of strategies using senses and one of them might suit the learners' preference. When this happens, teachers will be able to engage with the learners' learning and sustain their attention. By utilizing various strategies teachers can address mixed efficiencies of those learners as well as the dominant and secondary preferences of others. This will help to reinforce strong preferences and strengthen the weaker ones.

All in all, teachers and researchers have agreed that the multisensory approach is a powerful tool to reinforce learners' learning which includes word recognition. This can be seen in three ways which it helps learners to get the information across, process the information and helps them to easily grasp the information that they have already learned. By using various kinds of strategies through senses it simply opens up more doorways into the brain.

\section{Funding}

This research was supported by the grant from the Faculty of Education, Universiti Kebangsaan Malaysia GG-2019-017, KRA-2018-044 and PP-FPEND-2019.

\section{Conflicts of Interest}

The authors declare no conflicts of interest regarding the publication of this paper.

\section{References}

Abdullah, Y. L. P. K., Yunus, M. M., \& Hashim, H. (2019). Grammatical Errors in ESL Writing: An Error Analysis. International Journal of Recent Technology and Engineering, 8, 302-307. 
Chard, D. (2000). Phonics and Word Recognition Instruction in Early Reading Programs: Guidelines for Accessibility. http://www.ldonline.org/article/6316

Davis, J. B. (2011). The Effect of an Orton Gillingham Based Reading Intervention on Students with Emotional/Behaviour Disorders.

Don-Ezenne, I. N. (2014). Identification and Analysis of Problem of Word Recognition in Reading among JSS Students in Gwgwalada and Kwali Area Councils of Federal Capital Territory, Abuja. Journal of Research \& Method in Education, 4, 7-14. https://doi.org/10.9790/7388-04530714

Ewy, C. A. (2003). Teaching with Visual Frameworks: Focused Learning and Achievement through Instructional Graphics Co-Created by Students and Teachers. Thousand Oaks, CA: Corwin Press, Inc.

Hashim, H., \& Isa, I. S. M. (2012). Students' Anxiety Level towards Speaking in English: Malaysia Polytechnic Experience. In IEEE Symposium on Business, Engineering and Industrial Applications (pp. 595-599). Piscataway, NJ: IEEE. https://doi.org/10.1109/ISBEIA.2012.6422957

Jasmine, J., \& Connolly, M. (2015). The Use of Multisensory Approach during Centre Time, through Visual, Auditory, and Kinesthetic-Tactile Activities, to Enhance Spelling Accuracy of Second Grade Students.

Jensen, E. (1998). Teaching with the Brain in Mind. Alexandria: VA: Association for Supervision and Curriculum Development.

Johnson, G., \& Edelson, R. (2003). Integrating Music and Mathematics in the Elementary Classroom. Teaching Children Mathematics, 9, 474-479.

Maheshwari, V. K. (2016). Multi-Sensory Teaching-Meaning and Importance. http://www.vkmaheshwari.com/WP/?p=2364

Mohammadein, A. (2016). The Effect of Affection on English Language Learning of Children with Intellectual Disability Based on Total Physical Response Method of Language Teaching. International Journal of English Language and Literature Studies, 5, 92-103. https://doi.org/10.18488/journal.23/2016.5.2/23.2.92.103

Moustafa, A., \& Ghani, M. Z. (2016). The Effectiveness of a Multisensory Approach in Improving Letter-Sound Correspondence among Mild Intellectual Disabled Students in State of Kuwait.

Obaid, M. A. (2013). The Impact of Using Multi-Sensory Approach for Teaching Students with Learning Disabilities. Journal of International Education Research, 9, 75-82. https://doi.org/10.19030/jier.v9i1.7502

Philips, W. E., \& Feng, J. (2012). Methods for Sightword Recognition in Kindergarten: Traditional Flash Card Method vs Multisensory Approach.

Platt, S. (2015). The Effect of Multisensory Approach on Increasing Sight Word Automaticity in First Grade Students.

Skoning, S. (2010). Dancing the Curriculum. Kappa Delta Pi Record, 46, 170-174. https://doi.org/10.1080/00228958.2010.10516548

Stoffers, M. (2011). Using a Multi-Sensory Teaching Approach to Impact Learning and Community in a Second-Grade Classroom. Rowan DigitalWorks.

https://rdw.rowan.edu/cgi/viewcontent.cgi?article=1109\&context=etd

Thirusanku, J., \& Yunus, M. M. (2014). Status of English in Malaysia. Asian Social Science, 10, 254. https://doi.org/10.5539/ass.v10n14p254

Wilmes, B., Harrington, L., Kohler-Evans, P., \& Sumpter, D. (2008). Coming to Our Senses: Incorporating Brain Research Findings into Classroom Instruction. Education, $128,659-666$. 
Yunus, M. M., Salehi, H., \& John, D. S. A. (2013). Using Visual Aids as a Motivational Tool in Enhancing Students' Interest in Reading Literary Texts.

Zulkiflei, K., Yunus, M. M., \& Hashim, H. (2017). Positive Attitude Makes Good English. Really? In International Conference on Education and Regional Development. 